\title{
Characterization of Surface in Tool Hardened Exposed to Machining on Aluminum
} Alloy

Isaac Infante Palomino ${ }^{1}$, Noe Lopez Perrusquia ${ }^{1}$, Marco Doñu Ruiz ${ }^{1}$, Victor Olmos Domínguez ${ }^{2}$, Leopoldo Garcia Vanegas ${ }^{3}$ and Juan Juanico Loran ${ }^{1}$

${ }^{1}$ Universidad Politecnica del Valle de México, Tultitlan, Distrito Federal, Mexico, ${ }^{2}$ Universidad Tecnológica de México, ESTADO DE MÉXICO, Distrito Federal, Mexico, ${ }^{3}$ Universidad Tecnológica Fidel Velazquez, ESTADO DE MÉXICO, Distrito Federal, Mexico

Drilling is a manufacturing process based on machining, which demands cutting tools resistant to aggressive working environments and strong wear conditions [1]. A cutting tool is protected by applying coatings on the surface, permitting to increase the performance and service time on the production lines [2]. In recent years, innovations have been made in the process and/or techniques of boriding that permit the formation of coatings on the surface of cutting tools, with the objective of increased resistance to wear, corrosion and high temperatures [3-4].

Two drills; commercial and commercial with boriding treatment are exposed to a drilling process, to evaluate the wear on each tool. The results obtained show that the commercial boriding drill bit has an increased life in the machining process. The solid twist drill bit commercially in steel AISI M2 (Truper Mexico); with a diameter of $7 / 32$ in, tip angle of $130^{\circ}$ and helix angle of $35^{\circ}$, was exposed to the boriding process by dehydrated boron paste of reuse, with an temperature of $900{ }^{\circ} \mathrm{C}$, time of permanence 5 hours in a conventional furnace without controlled atmosphere. The commercial drill and the commercial boriding drill bit were subjected to a drilling process to manufacture blind holes on a 7075-T6 aluminum alloy, with refrigeration, using a three-axis CNC vertical machining center. The machining regime used was a cutting speed of $73 \mathrm{~m} / \mathrm{min}$, a feed speed of $0.089 \mathrm{~mm} / \mathrm{rev}$ and a cutting depth of $12.7 \mathrm{~mm}$. The characterization of the surface of the commercial drill bit and the commercial boriding drill bit, by the method of X-Ray Diffraction (XRD-Bruker D8 Advance, Cu radiation K $\alpha=1.5406 \AA$ ). For the analysis of the surface wear on drill bits after the machining test, was realized by SEM-EDS (JEOL, JSM-IT100, $20 \mathrm{kV}$ ). Figure 1a) shows the XRD pattern on the surface of the commercial boriding drill bit, revealing the presence of the Fe2B iron boride planes. Figure $1 \mathrm{~b}$ ) shows the planes of $\mathrm{Fe}_{2} \mathrm{~N}, \alpha-\mathrm{Fe}, \Upsilon-\mathrm{Fe}, \mathrm{Cr}_{2} \mathrm{~N}$ and Co obtained by XRD pattern on the surface of the commercial drill bit. Figure 2a) using SEM, shows the wear on the cutting edges of the commercial boriding drill bit; in addition the EDS spectrum analysis reveals the presence of Aluminum, Magnesium, Chrome and Zinc on the cutting edges of the drill bit after the machining test. Figure 2b) by SEM, shows abrasion, cutting edge wear and abrasive wear on the commercial drill bit; also adhesion of the aluminum alloy 7075-T6 on the cutting lip on the commercial drill bit; by EDS spectrum analysis reveals the presence of Aluminum, Vanadium. Molybdenum, Tungsten, Magnesium and Chrome on the surface after machining test. In relation to the summary of machining of drilling on aluminum 7075-T6, it reveals the service life for the commercial drill is 35 minutes and for the drill with treatment of boriding is 52 minutes. In relation to the machining summary of drilling on aluminum 7075-T6, shows the tool life; for the commercial drill bit the time is 35 minutes and the drill bit with boriding treatment the time is 52 minutes. In addition the final angle of the drill bits was determined; for the commercial boriding drill bit are $132^{\circ}$ and $132^{\circ} 48^{\prime}$ for the commercial drill bit. Likewise, an increase of $29 \%$ in the number of holes manufactured with the commercial drill bit boriding using dehydrated boron paste of reuse. The Boriding process permitted to extend the life of the tool exposed to drilling on an aluminum alloy 7075-T6. The results obtained in this study show a potential of the dehydrated boron paste reuse process. 

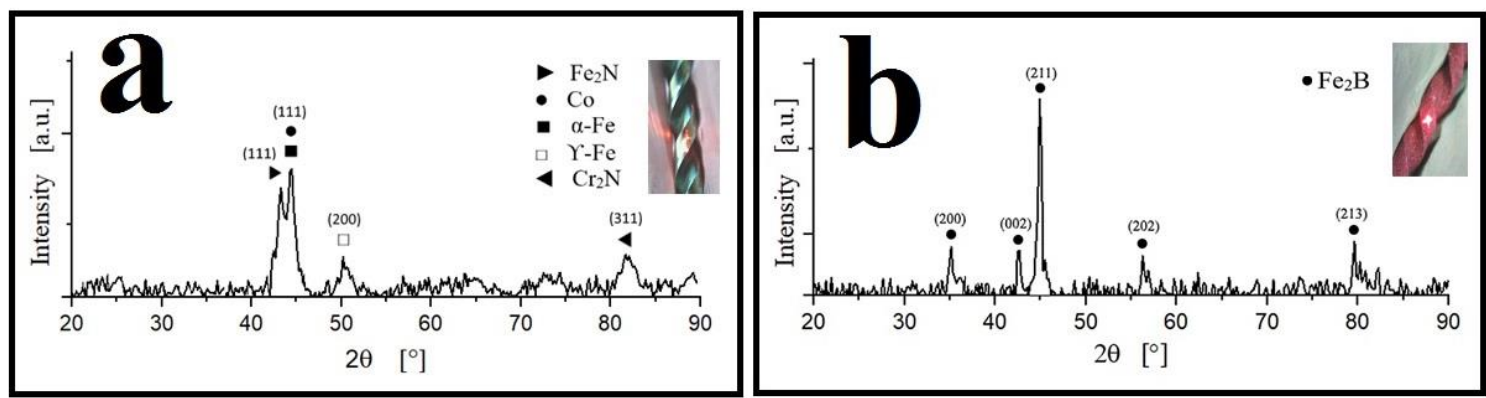

Figure 1. XRD patterns; (a) AISI M2 commercial steel drill bit and (b) AISI M2 commercial steel drill bit exposed to the Boriding process
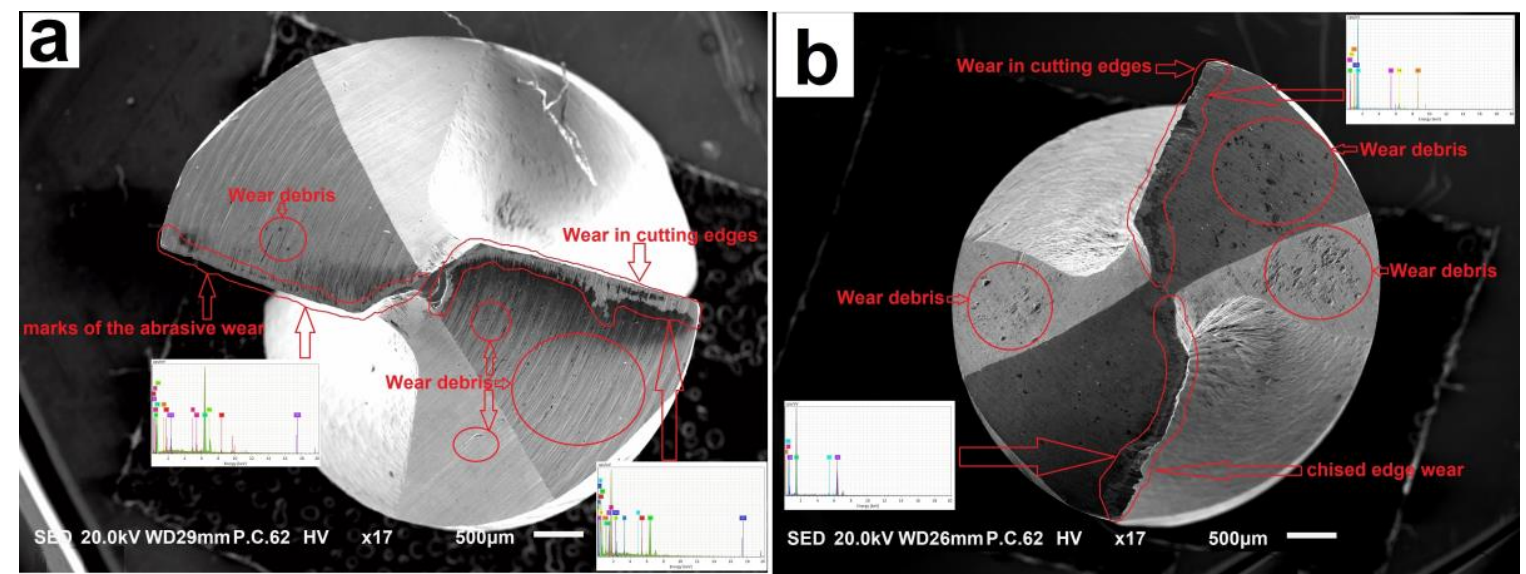

Figure 2. SEM and EDS images after the drilling process; (a) commercial AISI M2 steel drill bit and (b) commercial AISI M2 steel drill bit with Boriding treatment

\section{References}

[1] John N. Williard, et al. Microscopy and Microanalysis, 21(S3) (2015), p. 135-136

[2] Mahadi Hasan, et al, Journal of Manufacturing Processes, 29 (2017), p.343-375,

[3] I. Campos Silva, et al, Applied Surface Science 10 (2008), p. 2967-2974

[4] M.A Doñu Ruiz, et al, Thin Solid Films 596 (2015), p. 147-154 